\title{
OFFSHORE AND ONSHORE IDR MARKET: EVIDENCE ON INFORMATION SPILLOVER
}

\author{
Yayat Cadarajat and Alexander Lubis ${ }^{1}$
}

\begin{abstract}
This paper investigates the information transmission between off-shore and on-shore Rupiah currency markets Indonesian. We found the evidence of persistent volatility in all IDR/USD markets. Using EGARCH model on daily data for the period of 2008 - 2011, this paper provide several empirical conclusions.-First, the persistent volatility in all IDR/USD currency markets is evident. Second, the leverage effects are present in the rupiah exchange rates, indicating that IDR/USD markets have responded more to depreciation than appreciation, which is generally common in emerging market currencies. Third, the evidence of mean spillover are observed to be uni-directional; from NDF to both spot and forward rupiah markets. However, there are two ways return transmission between NDF and forward rate changes in the period of Europe crisis. Fourth, on the volatility, the spillover is only significant from NDF market to spot market for the entire period. However, in the time of crises, there is interdependence between volatility in offshore NDF and onshore spot rate changes, while information transmission is only valid from NDF to forward rate changes, not the other way around. Fifth, the negative spread of domestic interest rate may lead to depreciation pressure on the currency and positive spread may indicate the appreciation pressure.
\end{abstract}

Keywords: Foreign Exchange, Non-Deliverable Forward, exchange rate, spillover, EGARCH.

JEL Classification: F31, G13, C51

1 Yayat Cadarajat (yayat@bi.go.id) and Alexander Lubis (alexander@bi.go.id) are economist in Monetary Policy Group, Departmen of Economic Research and Monetary Policy, Bank Indonesia. The views expressed in this paper are of the authors and do not necessarily reflect those of Bank Indonesia. 


\section{PENDAHULUAN}

Sejak krisis mata uang Asia 1998, pasar valas Indonesia telah mengalami perkembangan yang signifikan. Perubahan besar dari rezim nilai tukar tetap ke mengambang terkendali kemudian menjadi mengambang (IMF EREAR, 2010), telah dilakukan oleh pemerintah. Lebih lanjut, pasar valas terus memberikan tekanan pada Rupiah, di mana pelaku asing dapat mengakses deliverable forward dari mata uang Rupiah, umumnya dari Singapura, baik untuk melakukan hedging untuk investasi mereka atau untuk tujuan spekulasi.

Dengan demikian Bank Indonesia mengeluarkan kebijakan yang membatasi kesempatan bagi pelaku asing dalam melakukan kegiatan spekulasi atas Rupiah². Transaksi Rupiah dibatasi hanya antara onshore bank dan non-resident. Hal ini mengurangi spekulasi atas mata uang Rupiah akibat adanya restriksi bagi bank domestic untuk memberikan pinjaman dalam mata uang Rupiah dan produk turunan yang terkait kepada non-resident. Inilah awal momentum dari Non Deliverable Forward (NDF) Rupiah.

NDF sendiri merupakan instrument valas derivatif yang diperdagangkan over-the-counter (OTC). Kontrak forward valas (forward foreign exchange contract) pada dasarnya merupakan kewajiban untuk membeli atau menjual sejumlah mata uang pada suatu waktu tertentu di masa mendatang, pada tingkat harga yang ditentukan dalam kontrak. Pihak yang terlibat dalam transaksi NDF, menyelesaikan transaksinya tidak dengan cara membayar dalam pasangan mata uang yang ditransaksikan (pair currency), melainkan dengan cara membayar dalam mata uang utama (biasanya dalam USD), sebesar selisih nilai tukar forward dan spot. NDF biasanya diperdagangkan melalui counter di pusat keuangan internasional seperti New York, London, Hong Kong dan Singapura. Sama dengan Indonesia, pasar NDF di negara Asia lainnya juga mengalami perkembangan paska krisis mata uang Asia. Rupiah Indonesia, merupakan pasar NDF terbesar di Asia dengan rata-rata volume transaksi harian diperkirakan sebesar USD 10 milyar, diikuti oleh Peso Philipina dan Renminbi China (Tabel 1). Dengan demikian, volatilitasnya juga merupakan yang terbesar.

Menarik untuk mencermati apakah produk yang diperdagangkan dalam dua jenis asset ini merefleksikan informasi yang sama. Perbedaan harga dapat mendorong arbitrase. Meski demikian, Parker (2001) menyatakan bahwa dalam kasus nilai tukar spot dan NDF dapat berbeda karena NDF berkembang akibat beberapa permasalahan pasar dan kendala investasi dari kebijakan regulator. Perkembangan NDF sendiri berasal dari kebutuhan investor asing untuk melakukan hedging atau untuk memperdagangkan mata uang yang diatur dan dikontrol secara ketat. Karena itu, sangat penting untuk mengetahui hubungan dan arus informasi antaraoffshore NDF dengan on-shore market.

Informasi tentang ini dapat bermanfaat bagi regulator dan investor. Bagi regulator, sangat sulit untuk mencapai tujuan ketika hubungan antara nilai tukar spot dan NDF sangat

2 Peraturan Bank Indonesia No. 3/3/2001, tanggal 12 Januari 2001 


\begin{tabular}{|c|c|c|c|c|c|c|}
\hline \multicolumn{7}{|c|}{$\begin{array}{c}\text { Tabel } 1 . \\
\text { Pasar NDF Mata Uang Asia }\end{array}$} \\
\hline \multicolumn{7}{|c|}{ Normal Market Condition } \\
\hline \multicolumn{4}{|c|}{ Onshore } & \multicolumn{3}{|c|}{ Offshore } \\
\hline & $\begin{array}{c}\text { average daily } \\
\text { volume (US\$bn) }\end{array}$ & $\begin{array}{l}\text { spot transaction } \\
\text { (US\$ mn) }\end{array}$ & $\begin{array}{c}\text { forward \& swap } \\
\text { transaction (US\$ mn) }\end{array}$ & $\begin{array}{c}\text { average daily } \\
\text { volume (US\$bn) }\end{array}$ & $\begin{array}{l}\text { NDF transaction } \\
\text { (US } \$ \mathrm{mn})\end{array}$ & $\begin{array}{c}\text { implied option } \\
\text { volatility spread (\%) }\end{array}$ \\
\hline CNY & $30.0-40.0$ & $5.0-10.0$ & $10.0-20.0$ & 3.0 & 10.0 & 0.2 \\
\hline KRW & 15.0 & $3.0-5.0$ & 50.0 & 4.0 & 5.0 & 0.4 \\
\hline INR & 9.0 & 5.0 & 10.0 & 1.1 & 5.0 & 0.4 \\
\hline PHP & 1.7 & $1.0-3.0$ & $5.0-10.0$ & $0.5-0.6$ & $10.0-20.0$ & 1.0 \\
\hline IDR & 1.3 & 2.0 & 10.0 & 0.7 & 10.0 & 1.0 \\
\hline MYR & 1.2 & $3.0-5.0$ & 10.0 & na & na & na \\
\hline THB & 1.1 & 3.0 & $30.0-50.0$ & 0.8 & na & $0.5-2.0$ \\
\hline
\end{tabular}

kuat. Kesulitan ini tidak hanya dalam menjaga stabilitas nilai tukar karena NDF diperdagangkan di luar negeri, tetapi juga dalam menerapkan kebijakan yang independen. Bagi investor, pemahaman tentang hubungan lintas pasar ini dapat merefleksikan strategi investasi mereka.

Dalam kasus pasar mata uang di Indonesia, banyak studi telah dilakukan. Meski demikian, paper ini lebih fokus pada pasar dalam negeri. Sepanjang pengetahuan penulis, studi yang menganalisis pasar NDF Rupiah masih terbatas. Kemungkinan penyebabnya adalah kesulitan dalam memperoleh data, karena NDF diperdagangkan melalui counter di luar negeri. Pada sisi lain, pergerakan pasar NDF telah menarik perhatian terutama bagi regulator. Secara khusus, tekanan atas mata uang Rupiah mengalami peningkatan selama krisis global. Untuk itu, paper ini akan mendiskusikan pasar NDF Rupiah ini.

Mengacu pada latar belakang ini, paper ini secara eksplisit bertujuan untuk menganalisis transmisi informasi antara pasar dalam dan pasar luar negeri mata uang Rupiah. Bagian selanjutnya dari paper ini akan mengulas teori dan studi literature terkait dengan pasar NDF. Bagian ketiga mengulas metodologi dan data yang digunakan. Hasil dan analisis akan diberikan pada bagian keempat, sementara bagian akhir akan memberikan kesimpulan.

\section{TEORI}

Berdasarkan Lipscomb (2005), perdagangan pasar NDF terutama dimulai pada awal 1990, dimulai dari produk untuk pihak yang akan melindungi posisi mereka terhadap perubahan nilai mata uang negara berkembang ataupun terhadap kemungkinan adanya restriksi mata uang yang tidak convertible. Seiring waktu, pasar NDF telah berkembang untuk mata uang negara yang investornya aktif baik dalam portofolio atau investasi langsung, atau di negara yang diperkirakan akan mengalami perubahan rezim nilai tukar yang signifikan. Sebaliknya, pasar 


\begin{tabular}{l|l}
\multicolumn{1}{c}{} & $\begin{array}{c}\text { Tabel } 2 . \\
\text { Mata Uang }\end{array}$ \\
\multicolumn{1}{c}{ Akses Non-Resident terhadap Pasar Domestik } \\
Renmibi China & Aksessibilitas \\
\hline Rupee India & Pihak asing tidak diperbolehkan berdagang di pasar lokal \\
\hline Won Korea & Diperbolehkan untuk keperluan transkasi \\
\hline Rupiah Indonesia & Diperbolehkan untuk keperluan transkasi \\
\hline Peso Philippines & Diperbolehkan untuk keperluan transkasi \\
\hline Dollar Taiwan & Diperbolehkan untuk keperluan transkasi \\
\hline Sumber: HSBC Emerging Market Currency Guide, 2011 & Pihak asing tidak diperbolehkan berdagang di pasar lokal \\
\hline
\end{tabular}

NDF untuk mata uang yang lebih fleksibel dalam konvertabilitas valas, justru mengalami penurunan yang substansial atau bahkan menghilang.

Seiring dengan peningkatan investasi di negara berkembang, pasar NDF juga meningkat untuk mata uang di Asia, khususnya setelah krisis 1997. NDF dapat dijadikan sebagai instrument pengganti untuk hedging oleh investor asing terkait dengan eksposur mata uang lokal, atau dijadikan sebagai instrument spekulasi.

Mungkin menarik bahwa Ringgit Malaysia dan Bath Thailand tidak termasuk dalam pasar NDF Asia yang utama meski tetap menetapkan restriksi atas konvertabilitas valas mereka. Misra dan Behera (2006) menyatakan ada beberapa kebijakan yang diterapkan untuk membatasi perkembangan NDF atas mata uangnya. Dalam kasus Malaysia, perubahan ke rezim nilai tukar tetap telah menghindarkan perkembangan lebih lanjut dari pasar NDF. Lebih lanjut, tidak adanya referensi nilai tukar juga menyebabkan penyelesaian NDF Ringgit Malaysia menjadi lebih sulit. Bank domestik di Malaysia tidak diperbolehkan melakukan transaksi forward dengan pihak asing, dan ini membatasi pihak asing tersebut untuk melakukan hedging atas posisi NDF mereka. Di Thailand, bank sentral Thailand menghambat bank asing untuk berpartisipasi dalam pasar NDF Bath Thailand melalui cabang-cabang mereka.

Penetapan harga pada hampir semua kontrak forward valas ditentukan oleh paritas suku bunga yang mengukur kesamaan imbal hasil untuk suatu rentang periode, suku bunga dua jenis mata uang, dan nilai tukar spotnya. Sebagaimana produk keuangan lainnya, ada factor-faktor lain yang berpengaruh terhadap harga NDF seperti arus perdagangan, likuiditas ${ }^{3}$, dan resiko. Ekspektasi perubahan rezim nilai tukar, posisi spekulatif, kondisi suku bunga lokal dan korelasi antara on-shore dan off-shore pasar forward, juga berkontribusi pada pergerakan harga NDF. Ketika investor asing memiliki sedikit akses

3 Perbedaan penetapan harga di pusat-pusat finansial karena ketersediaan penjual NDF, sebagai contoh harga NDF Rupiah di pasar New York dan Singapura lebih disebabkan oleh permasalahan likuiditas. 
terhadap suku bunga domestic, maka harga NDF akan lebih ditentukan oleh ekspektasi tingkat nilai tukar spot (Lipscomb, 2005).

Berdasarkan efficient market hypothesis, harga aset akan merefleksikan semua informasi secara sempurna. Arbitrase yang melibatkan instrument keuangan dengan harga yang sama antara dua pasar atau lebih, akan menyebabkan kerugian. Dengan demikian, pergerakan harga pada satu pasar akan diikuti oleh pergerakan harga pada pasar yang menjual instrument yang sama. Jika salah satu pasar tidak merespon pergerakan ini, maka satu pihak dapat mengambil keuntungan arbitrase diantara kedua pasar ini.

Hubungan pasar dalam dan luar negeri tanpa adanya kontrol lalu lintas modal, dapat diberikan dalam paritas suku bunga berikut:

$$
F=S(1+r) /\left(1+r^{\$}\right)
$$

Dimana $F$ adalah forward rate, $S$ adalah spot rate, $r$ adalah suku bunga domestik dan $r^{\$}$ adalah suku bunga asing (sebagai contoh US). Persamaan ini tercapai jika tidak ada halangan untuk transkasi lintas negara, termasuk dalam pinjam meminjam.

Meski demikian, ketika terdapat restriksi lalu lintas modal maka non-resident juga akan mengalami hambatan untuk mengakses pasar domestic. Karena itu, NDF akan menggantikan forward rate dan persamaannya akan menjadi:

$$
N D F=S(1+r) /\left(1+r^{\$}\right)
$$

Selain itu, yield spread antara dalam dan luar negeri merupakan indikasi adanya tekanan terhadap mata uang domestik. Jika suku bunga domestic lebih tinggi, maka implied yield dari NDF akan merefleksikan tekanan pada mata uang domestik. Namun demikian, kontrol atas modal dapat menghambat aliran masuk modal. Suku bunga domestik yang lebih rendah dari yield NDF dapat menunjukkan adanya tekanan depresiasi atas mata uang domestik, sementara spread nol menunjukkan tidak adanya tekanan baik untuk pasar di dalam maupun di luar negeri.

Studi literatur tentang korelasi antara NDF dengan nilai tukar spot dan forward cukup terbatas. Park (2001) merupakan salah satu literature awal yang melihat arus informasi antara nilai tukar spot Won Korea terhadap USD dengan pasar luar negeri NDF. Studi ini memiliki fokus pada dampak reformasi pada nilai tukar Korea, terutama terkait dengan hubungan antara pasar dalam dan luar negeri. Dengan menggunakan metode GARCH, studi ini menemukan bahwa selama periode sebelum reformasi, terdapat rambatan efek rata-rata dari spot ke pasar NDF tetapi tidak sebaliknya, dan terdapat fakta yang mendukung adanya rambatan volatilitas 
dua arah. Reformasi ini telah mengubah situasi dan membalikkan arah, dimana terdapat efek rambatan baik dalam nilai rata-rata maupun dalam hal volatilitas dari NDF ke pasar spot. Sebaliknya, dalam upayanya untuk menganalisis hipotesa pasar yang efisien atas perdagangan mata uang Renminbi, Izawa (2006) menemukan bahwa hipotesa ini ditolak dan NDF Renminbi bukan prediktor yang tidak bias untuk nilai tukar mendatang.

Ma et.al. (2004) menemukan bahwa NDF Asia secara umum tidak terhubung kuat ke nilai tukar spot mata uang pasangan karena adanya kontrol dan upaya kuat untuk mengarahkan pergerakan mata uang ini. Lebih lanjut, studi ini juga menunjukkan bahwa NDF Asia memiliki korelasi silang yang positif diantara mereka dibandingkan terhadap pasar spot selama rentang periode Maret 2001 - Februari 2004. Manajemen mata uang oleh otoritas di Asia cenderung membatasi respon nilai tukar spot terhadap volatilitas pasar global sehingga rate NDF bergerak dengan tingkat volatilitas yang lebih besar dibandingkan dengan pasar spot, (Cairns et.al., 2007).

Lebih lanjut, Colavecchio dan Funke (2006) menggunakan GARCH multivariate untuk menganalisis volatilitas antara pasar NDF China dengan tujuh pasangan negaranya di Asia Pasifik selang periode Januari 1998 - Maret 2005. Studi ini menemukan bahwa NDF Renminbi menentukan rate mata uang negara Asia dalam berbagai tingkatan. Meskipun demikian, mereka mencatat arah pergerakan terbalik dalam volatilitas dari NDF ke pasar spot meski dengan magnitude yang lemah.

Terkait penggunaan model ARCH-GARCH dalam menganalisis mekanisme transmisi informasi pasar mata uang, kami mengikuti Park (2001) dan Misra dan Behera (2006). Penggunaan EGARCH model dipilih untuk menangkap kemungkinan asimtery dan volatility clustering secara simultan. Isu asimetri ini telah dibahas oleh Michayluk et.al. (2000) dan Christiansen (2003) menggunakan EGARCH untuk menganalisis rambatan volatilitas dan ratarata atas data pasar keuangan.

Secara umum, analisa di atas mencatat adanya saling keterkaitan lintas berbagai NDF mata uang dan antara pasar NDF dalam dan luar negeri. Dengan demikian, studi atas perilaku NDF Rupiah dan keterkaitannya dengan nilai tukar dan pasar forward, akan memberikan manfaat bagi pelaku pasar dan juga bagi regulator.

\section{METODOLOGI}

Kami menggunakan Augmented Dickey -Fuller (ADF) tests digunakan untuk menguji stasionaritas data. Lebih lanjut, uji kointegrasi Johansen dilakukan untuk menginvestigasi hubungan jangka panjang antara rate NDF luar negeri dan nilai tukar spot dan forward. Untuk uji sensitivitas hasil estimasi terkait dengan pemilihan panjang lag, prosedur yang umum digunakan adalah estimasi Vector Autoregression (VAR) pada data level, untuk 
menentukan panjang lag yang optimal (Enders, 2004). Selanjutnya, kami memilih kriteria Hannan - Quinn (HQC) sesuai dengan Johansen. Uji LM digunakan untuk mendeteksi adanya korelasi serial pada error. Selain itu uji kausalitas Granger digunakan untuk menguji arah hubungan antara NDF luar negeri dan perubahan nilai tukar dalam negeri.

Untuk menganalisa transmisi informasi dalam dan luar negeri atas mata uang Rupiah, penulis lanjutkan dengan analisis volatilitas dan mengaplikasikan pengembangan model EGARCH(p,q) bivariatdari Nelson (1991) untuk melihat apakah volatilitas return NDF mempengaruhi atau dipengaruhi oleh volatilitas spot dan forward. EGARCH memiliki tiga keuntungan fundamental dibandingkan dengan model GARCH dari Bollerslev (1986; (i) model standar GARCH tidak dapat menangkap perilaku asimetrik dari conditional variance dalam harga asset, (ii) berbeda dengan model standar GARCH dimana parameter model harus direstriksi positif untuk memastikan conditional variance akan positif sepanjang periode, maka dalam model EGARCH restriksi ini tidak diperlukan karena bentuknya yang eksponensial, (iii) persistensi conditional variance dapat ditangkap dalam model EGARCH yang dikontrol oleh koefisien dari lag-nya, sementara hal ini sulit ditangkap dengan menggunakan model standar GARCH.

Estimasi dilakukan dengan model dua langkah sebagaimana dilakukan oleh Hamao et.al. (1990), Park (2001), Ng (2000) dan Christiansen (2003). Model standar EGARCH(p,q) yang digunakan dalam studi ini diwakili oleh conditional mean dan conditional variance sebagaimana persamaan berikut:

$$
\begin{aligned}
R_{i, t}=\alpha_{i} & +\Phi_{i} \varepsilon_{i, t-1}+\varepsilon_{i, t} \\
\ln \left(\sigma_{i, t}^{2}\right)= & \omega_{i}+\sum_{k=1}^{p} \beta_{i, k}\left|\frac{\varepsilon_{i, t-1}}{\sqrt{\sigma_{i, t-1}}}-\sqrt{2 / \pi}\right|+\sum_{k=1}^{p} \delta_{i, k} \frac{\varepsilon_{i, t-1}}{\sqrt{\sigma_{i, t-1}}} \\
& +\sum_{k=1}^{p} \theta_{i, k} \ln \left(\sigma_{i, t-1}^{2}\right)
\end{aligned}
$$

Dimana $R_{i, t}$ menunjukkan returnpasar mata uang IDR/USD termasuk NDF luar negeri, nilai spot and forward dalam negeri. Kami menambahkan $\varepsilon_{i, t-1}$ or MA(1) ke persamaan rata-rata untuk mendeteksi adanya korelasi serial dalam pergerakan nilai tukar. IDR/USD ini digunakan untuk menginvestigasi hubungan litas return mata uang. Error stokastik $\left(\varepsilon_{i, t}\right)$ diambil dan digunakan dalam model EGARCH.

Persamaan (2) merupakan spesifikasi conditional variance dimana $\omega_{i}$ adalah konstanta atau rata-rata varian, $\frac{\varepsilon_{i, t-1}}{\sqrt{\sigma_{i, t-1}}}$ adalah standardized residuals dari return nilai tukar, sementara suku $\mathrm{ARCH}$, memberikan informasi tentang dampak informasi periode sebelumnya terhadap 
volatilitas return. Jika $\frac{\varepsilon_{i, t-1}}{\sqrt{\sigma_{i, t-1}}}$ positif, maka efek inovasi terhadap conditional variance adalah $-\delta_{i, k}+\beta_{i, k}$. Lebih lanjut, koefisien $\beta_{i, k}$ mengukur volatility clustering pada semua series.

Sudah cukup umum bahwa pasar mata uang memiliki autokorelasi dalam volatilitasnya. Parameter $\beta_{i, k}$ yang signifikan dapat memberikan informasi tentang volatilitas pasar IDR/USD yang dipengaruhi oleh perubahan volatilitas historisnya. Autokorelasi dalam volatilitas sering dijumpai pada pasar mata uang. Lebih jauh, $\sigma_{i, t}^{2}$ menunjukkan conditional variancedari return nilai tukar. Lag dari conditional variance $\left(\sigma_{i, t-1}^{2}\right)$ menunjukkan forecast varians periode sebelumnya yang merupakan komponen $\mathrm{GARCH}$, yang dapat berpengaruh terhadap volatilitas.Shock informasi dalam pasar, cenderung memiliki dampak yang kontinyu terhadap volatilitas berikutnya. Koefisien dari komponen GARCH yang signifikan secara statistik dapat menunjukkan persistennya volatilitas.

Terkait dengan pemilihan panjang lag yang optimal, tiga kriteria yang sering digunakan adalah Akaike Information Criteria (AIC), Schwartz (Bayesian) Information Criteria (SIC) dan Hannan-Quinn Criteria (HQC). Lag dipilih berdasarkan HQC. Shittu dan Asemota (2009) menemukan bahwa HQC lebih baik untuk sampel yang besar, sementara AIC paling sesuai untuk sampel yang kecil.

Uji residu dilakukan untuk menilai efisiensi model. LM diaplikasikan untuk mengidentifikasi kemungkinan masih adanya efek ARCH. Pengujian keberadaan conditional heterskedastisitas dilakukan dengan meregres kuadrat residu terhadap konstan dan lagnya sampai order ke q. Tes LM memiliki hipotesa nol tidak ada lagi efek ARCH. Lebih lanjut, pengujian adanya serial korelasi antara NDF dan perubahan nilai tukar spot dan forward juga dilakukan. Ljung-Box (LB) $\mathrm{Q}(12)$ dan L-B $\mathrm{Q}^{2}(12)$ diestimasi untuk melihat linear dan non-linear dependensi (autocorrelation) pada semua series.

Pada model ARCH dan GARCH, variabel eksogen dimasukkan kedalam persamaan mean, dan juga ke persamaan varians. Pengembangan model ditunjukkan berikut:

$$
\begin{aligned}
R_{i, t}=\alpha_{i} & +\Phi_{i} \varepsilon_{i, t-1}+\partial_{i} R_{j, t-1}+\varepsilon_{i, t} \\
\ln \left(\sigma_{i, t}^{2}\right)=\omega_{i} & +\sum_{k=1}^{p} \beta_{i, k}\left|\frac{\varepsilon_{i, t-1}}{\sqrt{\sigma_{i, t-1}}}-\sqrt{2 / \pi}\right|+\sum_{k=1}^{p} \delta_{i, k} \frac{\varepsilon_{i, t-1}}{\sqrt{\sigma_{i, t-1}}} \\
& +\sum_{k=1}^{p} \theta_{i, k} \ln \left(\sigma_{i, t-1}^{2}\right)+\gamma_{i} \varepsilon_{j, t-1}^{2}
\end{aligned}
$$

Dalam Persamaan (3) dan (4), kita masukkan hasil estimasi EGARCH( $p, q)$ dengan persamaan (1) dan (2). Jika $R_{i, t}$ adalah return NDF, maka kita bisa memasukkan $R_{j, t-1}$ sebagai return dari onshore IDR/USD spot atau forward kedalam persamaan mean. Koefisien $\partial_{i}$ yang 
signifikan menunjukkan bahwa ada mean spilover antara perubahan nilai tukar offshore dan onshore. Selain itu, pengembangan persamaan conditional variance dilakukan dengan menambahkan $\varepsilon_{j, t-1}^{2}$, squared standardized innovation periode sebelumnya, kedalam persamaan $R_{j t}$. Koefisien $\gamma_{i}$ menguji apakah rambatan volatilitas ada lintas offshore NDF dengan pasar domestic IDR.

\section{HASIL DAN ANALISIS}

\subsection{Analisis Awal}

NDF Rupiah (IDR) diperdagangkan dalam jumlah yang besar di Singapura dan sejumlah kecil di Hong Kong dan New York. Kebutuhan untuk menghedge instrument Rupiah merupakan salah satu alasan diperdagangkannya NDF Rupiah. Pasar on-shore forward yang tipis mendorong kebanyakan investor mencari perlindungan instrument pada pasar luar negeri. Alasan lain adalah menyediakan instrumen bagi investor asing untuk melakukan spekulasi terhadap mata uang Rupiah. Investor asing tidak diperbolehkan mengakses pasar dalam negeri selain untuk aktifitas ekonomi yang melandasinya ${ }^{4}$.

Hampir semua pemain pasar NDF Rupiah adalah investor asing. Hal ini dikarenakan bank dilarang melakukan margin trading dalam perdagangan mata uang Rupiah ${ }^{5}$. Meskipun demikian, bank domestik dimungkinkan terlibat dalam perdagangan secara margin trading untuk mata uang dalam kondisi tertentu.

Dalampasar, terdapat bid ask spread yang menunjukkan biaya transaksi termasuk persepsi resiko dalam pasar. Pasar yang lebih dalam dapat menekan bid ask spread. Dari data harian periode 3 Januari 2011 sampai 21 Oktober 2011, Rupiah mencatat bid ask spread tertinggi baik di pasar spot dalam negeri, maupun pasar NDF luar negeri (Tabel 3). Ini mencerminkan terjadinya penurunan likuiditas pada pasar tersebut dibandingkan dengan pasar di negara Asia.

\begin{tabular}{|c|c|c|c|c|c|c|}
\hline \multicolumn{7}{|c|}{$\begin{array}{c}\text { Tabel } 3 . \\
\text { Bid Ask Spread Pasar Mata Uang Asia tahun } 2011 \text { (Sampai19 Oktober 2011) }\end{array}$} \\
\hline & \multicolumn{2}{|c|}{ SPOT } & \multicolumn{2}{|c|}{ FORWARD 1M } & \multicolumn{2}{|c|}{ NDF $1 M$} \\
\hline & $\begin{array}{l}\text { Onshore } \\
\text { bid/ask spread }\end{array}$ & $\begin{array}{l}\text { Volatility } \\
\text { 10D }\end{array}$ & $\begin{array}{l}\text { Onshore } \\
\text { bid/ask spread }\end{array}$ & $\begin{array}{l}\text { Volatility } \\
\text { 10D }\end{array}$ & $\begin{array}{l}\text { Offshore } \\
\text { bid/ask spread }\end{array}$ & $\begin{array}{l}\text { Volatility } \\
10 \mathrm{D}\end{array}$ \\
\hline IDR & 8,01 & 0,36 & 0,09 & 1,47 & 19,51 & 2,29 \\
\hline KRW & 1,56 & 0,90 & 493,92 & 5,83 & 0,06 & 0,50 \\
\hline PHP & 0,05 & 0,90 & 0,05 & 0,90 & 1,19 & 0,77 \\
\hline MYR & 0,00 & 1,06 & 0,08 & 1,02 & 0,00 & 0,59 \\
\hline CNY & 0,00 & 0,64 & 0,43 & 10,65 & 0,00 & 0,15 \\
\hline
\end{tabular}

4 Bank Indonesia Regulation No. 10/28/PBI/2008

5 Bank Indonesia Regulation No. 7/31/PBI/2005 
Pada sisi lain, volatilitas pada pasar spot Rupiah merupakan yang terendah diantara negara Asia lainnya, sementara volatilitas NDF tercatat sebagai yang tertinggi. Hal ini terkait dengan intervensi yang dilakukan Bank Indonesia pada pasar spot, yang berhasil menurunkan volatilitas pasar dalam negeri.

Jika pasar Rupiah dilihat lebih dekat, kondisi likuiditas telah mengalami perbaikan paska krisis subprime yang mengalami puncaknya ditandai dengan kebankrutan Lehman Brothers (Tabel 4). Data juga mengindikasikan bahwa likuiditas dalam negeri lebih baik dibandingkan dengan pasar luar negeri. Hal ini dapat dilihat dari bid ask spread pasar domestik yang lebih rendah dibandingkan pasar luar negeri.

\begin{tabular}{|c|c|c|c|c|c|c|c|c|c|c|c|c|}
\hline \multicolumn{13}{|c|}{$\begin{array}{c}\text { Tabel } 4 . \\
\text { Bid-Ask Spread Rupiah pada Pasar Valas Luar Negeri }\end{array}$} \\
\hline & \multicolumn{4}{|c|}{ SPOT } & \multicolumn{4}{|c|}{ 1M FORWARD } & \multicolumn{4}{|c|}{ 1M NDF } \\
\hline & 2008 & 2009 & 2010 & 2011*) & 2008 & 2009 & 2010 & 2011*) & 2008 & 2009 & 2010 & 2011*) \\
\hline Bid-Ask Spread & & & & & & & & & & & & \\
\hline - Average & 32.30 & 24.42 & 9.00 & 8.00 & 45.14 & 41.57 & 14.39 & 11.09 & 73.17 & 71.42 & 19.27 & 17.14 \\
\hline - Min & 3.00 & 5.00 & 1.00 & 1.00 & 0.00 & 0.00 & 0.00 & 0.00 & 0.00 & 0.00 & 0.00 & 0.00 \\
\hline - Max & 250.00 & 100.00 & 30.00 & 30.00 & 300.00 & 522.00 & 577.50 & 106.00 & 400.00 & 300.00 & 65.00 & 88.00 \\
\hline
\end{tabular}

Pada tahun 2008 dan 2009, pasar dalam negeri Indonesia terkena dampak dari goncangan global. Bid ask spread minimum dan maksimum pada pasar spot domestik mencatat perbedaan yang sangat besar dari Rp3 ke Rp250 pada tahun 2008, dan dari Rp5 ke Rp 100 pada tahun 2009. Hal yang sama juga terjadi pada pasar NDF domestik. Hal ini kemungkinan merefleksikan periode dimana likuiditas pada pasar domestik mengalami tekanan akibat permintaan aliran modal keluar. Meski demikian, pada tahun 2010 dan 2011, krisis hutang Eropa telah memacu aliran dana ke negara berkembang, dan akibatnya likuiditas baik pada pasar domestik maupun luar negeri mengalami perbaikan. Bid ask spread rata-rata pada pasar spot Rupiah mengalami penurunan drastis menjadi Rp 9 pada tahun 2010, dan Rp 8 pada tahun 2011. Penurunan yang sama juga terjadi pada pasar NDF. Deviasi antara bid ask spread minimum dan maksimum juga mengalami penurunan. Namun untuk pasar forward NDF dalam negeri, bid ask spread ini

\begin{tabular}{|l|c|}
\hline \multicolumn{2}{|c|}{ Tabel. 5 Volatilitas Rupiah } \\
Tahun 2011 (Sampai 19 Oktober 2011) \\
\hline \multicolumn{1}{|c|}{ MARKET } & VOLATILITY \\
\hline Spot & 0.36 \\
\hline Forward & 1.47 \\
\hline 1M NDF & 2.30 \\
\hline Sumber: Reuters, Perhitungan Penulis \\
\hline
\end{tabular}


masih tinggi pada masa sebelum hari libur. Hal ini dapat menunjukkan bahwa akibat tingginya ketidakpastian pada pasar global sementara pasar Indonesia mengalami jeda panjang, telah menciptakan kebutuhan bagi investor untuk menghedge posisi mereka. Dengan demikian, ini akan memberikan tekanan likuiditas pada pasar.

\subsection{Hasil Estimasi}

Studi ini menggunakan data harian dari tahun 2008 sampai 2011. Selain itu, studi ini juga mengamati interaksi informasi antara pasar Rupiah dalam dan luar negeri selama krisis Subprime dan krisis hutang pemerintah di Eropa. Krisis subprime menunjukkan periode dimana Rupiah mengalami tekanan depresiasi yang tinggi, sementara krisis hutang Eropa justru menunjukkan periode adanya tekanan apresiasi. Dengan demikian, perbedaan jenis tekanan ini akan memberikan dampak yang berbeda dalam interaksi informasi.

Uji ADF menunjukkan bahwa semua data return memiliki unit root pada level, namun tidak pada first difference.

\begin{tabular}{l|c|c|c}
\multicolumn{3}{c}{ Tabel 6. } \\
\multicolumn{3}{|c|}{ Augmented Dickey-Fuller Unit Root Test } \\
\hline Full sample & Critical Value & Level & First Difference \\
\hline Spot & $-3.97(1 \%)$ & -1.75 & -28.82 \\
Forward & $-3.97(1 \%)$ & -2.27 & -27.43 \\
NDF & $-3.97(1 \%)$ & -2.25 & -29.36 \\
\hline Sub-sample I: Subprime crisis & $-3.99(1 \%)$ & -1.67 & \\
\hline Spot & $-3.99(1 \%)$ & -2.42 & -15.58 \\
Forward & $-3.99(1 \%)$ & -2.18 & -15.44 \\
NDF & $-3.44(1 \%)$ & -1.11 & \\
\hline Sub-sample II: Europe sovereign crisis & -1.85 & -23.88 \\
\hline Spot & $-3.44(1 \%)$ & -2.73 & -24.92 \\
Forward & $-3.44(1 \%)$ & -11.42 \\
\hline NDF &
\end{tabular}

Tabel 7 menunjukkan statistik deskriptif untuk NDF, perubahan nilai tukar spot dan forward. Rata-rata negative ditemukan baik pada full sampel maupun pada sub sample 2 (krisis hutang pemerintah Eropa), sementara sub sampel 1 (krisis subprime) memiliki rata-rata yang positif. Pada sub sample 2, perubahan NDF menunjukkan standar deviasi tertinggi yakni 0,5\%, dibandingkan dengan 0,3\% dan 0,4\% masing-masing untuk nilai tukar spot dan forward. Gambaran awal ini mengindikasikan semua series nilai tukar bersifat non-Gausian, yakni tidak 
terdistribusi normal. Akhirnya, uji Ljung-Box atas return dan kuadrat residumenunjukkan bahwa volatilitas data ini berubah sepanjang waktu dan bersifat tercluster (volatility clustering). Ini terlihat dari signifikannya Q(12) maupun $Q^{2}(12)$. Hal ini menunjukkan adanya ketergantungan linear dan non linear sehingga membutuhkan ARCH atau GARCH untuk menangkap efek ARCH tersebut.

\begin{tabular}{|c|c|c|c|c|c|c|c|}
\hline \multicolumn{8}{|c|}{$\begin{array}{c}\text { Tabel } 7 . \\
\text { Statistik Deskriptif untuk Perubahan Pasar Forward, NDF dan Spot }\end{array}$} \\
\hline & Mean $\left(\times 10^{3}\right)$ & Std. Dev. & Skewness & Kurtosis & JB & $Q(12)$ & $Q^{2}(12)$ \\
\hline \multicolumn{8}{|c|}{ Full sample } \\
\hline Forward & -0.038 & 0.020 & -0.948 & 366.994 & 5277732 & 185.300 & 239.18 \\
\hline NDF & -0.038 & 0.009 & 1.839 & 21.096 & 13582.1 & 27.336 & 627.86 \\
\hline Spot & -0.042 & 0.006 & 1.609 & 58.660 & 123819.3 & 51.767 & 32.857 \\
\hline \multicolumn{8}{|c|}{ Sub-sample I: Subprime crisis } \\
\hline Forward & 0.858 & 0.035 & -0.639 & 123.363 & 175073.8 & 60.301 & 72.10 \\
\hline NDF & 0.878 & 0.014 & 1.565 & 11.957 & 1087.7 & 23.933 & 157.53 \\
\hline Spot & 0.801 & 0.008 & 1.564 & 41.237 & 17785.0 & 33.067 & 7.9681 \\
\hline \multicolumn{8}{|c|}{ Sub-sample II: Europe sovereign crisis } \\
\hline Forward & -0.071 & 0.004 & 0.422 & 12.880 & 1655.0 & 42.543 & 93.481 \\
\hline NDF & -0.063 & 0.005 & 0.965 & 14.088 & 2132.2 & 51.713 & 276.45 \\
\hline Spot & -0.075 & 0.003 & 2.142 & 28.861 & 11567.3 & 30.378 & 57.099 \\
\hline
\end{tabular}

Dua data yang tidak stasioner dapat dikatakan terkointegrasi jika terdapat kombinasi linear diantara keduanya yang stasioner. Kondisi ini menunjukkan kedua variable tersebut bergerak seirama sepanjang waktu, dan dikatakan memiliki hubungan kointegrasi. Dalam pengujian kointegrasi, mengikuti metode Johansen, kami menemukan bahwa NDF luar negeri dan nilai tukar spot dan forward, memiliki hubungan yang stasioner meski secara individu tidak. Ini menunjukkan adanya hubungan jangka panjang yang stabil diantara ketiga variabel tersebut. Koefisien kointegrasi bernilai hampir satu, membuktikan adanya hubungan jangka panjang ini. Karena itu, kami menggunakan perubahan nilai tukar dalam estimasi efek rambatan.

Dalam menganalisa mekanisme transmisi informasi, digunakan uji kausalitas Granger untuk melihat arah kausalitas antara pasar mata uang dalam dan luar negeri. Upaya ini secara khusus dilakukan untuk mencermati keterkaitan antara lead-lag volatilitas antar pasar. Uji kausalitas Granger ini melibatkan penggunaan uji-F untuk melakukan join test tentang apakah informasi terdahulu pada pasar i mampu memberikan informasi tentang pasar $j$, ketika informasi terdahulu tentang pasar $j$ ini juga tersedia.

Tabel 9 menampilkan hasil uji kausalitas Granger. Kami menemukan hubungan dua arah antara NDF dan pasar spot untuk keseluruhan sample, meski efek dari perubahan pasar spot 


\begin{tabular}{|c|c|c|c|}
\hline \multicolumn{4}{|c|}{$\begin{array}{c}\text { Tabel } 8 . \\
\text { Johansen Cointegration Test }\end{array}$} \\
\hline $\begin{array}{l}\text { Hypothesized } \\
\text { No. of CE(s) }\end{array}$ & Eigenvalue & $\begin{array}{l}\text { Trace } \\
\text { Statistic }\end{array}$ & $\begin{array}{l}5 \% \text { Critical } \\
\text { Value }\end{array}$ \\
\hline \multicolumn{4}{|l|}{ Full sample } \\
\hline \multicolumn{4}{|l|}{$N D F=-1.102 * S P O T$} \\
\hline None * & 0.099 & 101.751 & 15.495 \\
\hline At most 1 & 0.002 & 2.145 & 3.841 \\
\hline \multicolumn{4}{|l|}{$N D F=-1.045^{\star} F W D$} \\
\hline None * & 0.288 & 326.744 & 15.495 \\
\hline At most 1 & 0.003 & 3.114 & 3.841 \\
\hline \multicolumn{4}{|c|}{ Sub-sample I: Subprime crisis } \\
\hline \multicolumn{4}{|l|}{$N D F=-1.121^{\star} S P O T$} \\
\hline None * & 0.113 & 35.007 & 15.495 \\
\hline At most 1 & 0.002 & 0.606 & 3.841 \\
\hline \multicolumn{4}{|l|}{$N D F=-1.052^{*} F W D$} \\
\hline None * & 0.344 & 121.940 & 15.495 \\
\hline At most 1 & 0.005 & 1.344 & 3.841 \\
\hline \multicolumn{4}{|c|}{ Sub-sample II: Europe sovereign crisis } \\
\hline \multicolumn{4}{|l|}{$N D F=-0.995^{\star} S P O T$} \\
\hline None * & 0.050 & 22.189 & 15.495 \\
\hline At most 1 & 0.004 & 1.769 & 3.841 \\
\hline \multicolumn{4}{|l|}{$N D F=-0.996^{\star} F W D$} \\
\hline None * & 0.036 & 16.662 & 15.495 \\
\hline At most 1 & 0.005 & 2.114 & 3.841 \\
\hline
\end{tabular}

domestik terhadap NDF luar negeri relatif lebih rendah dibandingkan arah sebaliknya. Lebih lanjut, hasil ini juga ditemukan untuk periodisasi 2, yakni ketika terjadi krisis hutang pemerintah di Eropa.

Hal yang berbeda ditemukan untuk periodisasi 1 yakni ketika terjadi krisis subprime di Amerika Serikat. Pada periode ini, hanya terdapat hubungan satu arah dari perubahan NDF ke pasar forward. Ini menunjukkan bahwa shock yang bersumber dari pasar (seperti NDF luar negeri), memiliki pengaruh yang signifikan terhadap volatilitas pasar yang lain (yakni pasar spot dan forward dalam negeri).

Hasil pendahuluan di atas mengindikasikan adanya autokorelasi dan conditional heteroscedasticity yang kuat, sebagaimana umumnya yang terjadi pada data harian. Ini memerlukan penggunaan $\mathrm{MA}(1)-\mathrm{EGARCH}(p, q)$ untuk menangkap efek $\mathrm{ARCH}$.

Awalnya kami mengestimasi univariate $\operatorname{EGARCH}(p, q)$ berdasarkan Persamaan (1) dan (2). Estimasi dilakukan untuk keseluruhan sampel mencakup 956 observasi dari 20 Februari 


\begin{tabular}{|c|c|c|}
\hline \multicolumn{3}{|c|}{$\begin{array}{c}\text { Tabel } 9 . \\
\text { Granger Casuality Test }\end{array}$} \\
\hline Null Hypothesis: & F-Statistic & p-values \\
\hline \multicolumn{3}{|l|}{ Full sample } \\
\hline DLNDF does not Granger Cause DLFWD & 65.054 & 3.E-38 \\
\hline DLFWD does not Granger Cause DLNDF & 1.416 & 0.2366 \\
\hline DLSPOT does not Granger Cause DLNDF & 6.508 & 0.0002 \\
\hline DLNDF does not Granger Cause DLSPOT & 25.209 & $1.0 \mathrm{E}-15$ \\
\hline \multicolumn{3}{|l|}{ Sub-sample I: Subprime crisis } \\
\hline DLNDF does not Granger Cause DLFWD & 25.274 & 8.0E-11 \\
\hline DLFWD does not Granger Cause DLNDF & 0.598 & 0.5508 \\
\hline DLSPOT does not Granger Cause DLNDF & 4.795 & 0.0294 \\
\hline DLNDF does not Granger Cause DLSPOT & 22.815 & $3.0 \mathrm{E}-06$ \\
\hline \multicolumn{3}{|l|}{ Sub-sample II: Europe sovereign crisis } \\
\hline DLNDF does not Granger Cause DLFWD & 7.658 & $6.0 \mathrm{E}-06$ \\
\hline DLFWD does not Granger Cause DLNDF & 4.896 & 0.0007 \\
\hline DLSPOT does not Granger Cause DLNDF & 4.477 & 0.0006 \\
\hline DLNDF does not Granger Cause DLSPOT & 11.743 & $1.0 \mathrm{E}-10$ \\
\hline
\end{tabular}

2008 sampai 19 Oktober 2011. Sebagai tambahan, estimasi dilakukan dengan sub sample 1 yang mencakup 290 observasi untuk periode 20 Februari 2008 sampai 31 Maret 2009, sementara untuk sub sampel kedua, mencakup 405 observasi untuk periode 1 April 2010 sampai 19 Oktober 2011.

Tabel 10 menunjukkan model terbaik untuk estimasi sampel keseluruhan. Orde ARCH dan GARCH yang berbeda diaplikasikan untuk series yang berbeda, mengacu pada HQC. Model terbaik untuk perubahan nilai tukar spot Rupiah adalah $\operatorname{EGARCH}(1,2)$ sementara $\operatorname{EGARCH}(1,4)$ dan $\operatorname{EGARCH}(1,1)$ masing-masing untuk pasar forward dan NDF.

Statistik Ljung-Box Q(12) dan $\mathrm{Q}^{2}(12)$ untuk residu EFARCH yang ternormalisasi terbukti signifikan, menunjukkan bahwa spesifikasi model sudah tepat. Selain itu, uji LM(12) juga mengkonfirmasi hipotesa nol tentang tidak adanya efek ARCH yang tersisa.

Dengan hasil pengujian model ini, return pasangan negara pasangan, $\left(R_{\mathrm{j}, \mathrm{t}-1}\right)$, disertakan dalam persamaan rata-rata sebagai variabel penjelas. Sama halnya, standardized residual dari model $\mathrm{EGARCH}(p, q)$ juga disertakan dalam persamaan varian sebagai variabel eksogen. Tabel 8 s.d. 10 menunjukkan hasil estimasi untuk keseluruhan sampel, sub sampel 1 dan sub sampel 2. 
Koefisien dari persistensi volatilitas $\theta_{i, k^{\prime}}$ seluruhnya signifikan untuk pasar spot, NDF, dan forward. Wu (2005) mencatat bahwa syarat agar volatilitas stabil adalah $\sum_{k=1}^{p} \theta_{i, k}$ harus lebih kecil dari satu. Hasil yang diperoleh memenuhi kriteria ini dan menunjukkan persisttensi volatilitas bersifat stabil. Hal ini berlaku untuk pasar spot, NDF, dan forward untuk keseluruhan sample.

Dalam hal rambatan, hasil estimasi menunjukkan adanya efek rambatan satu arah dari NDF ke pasar spot dan forward Rupiah. Hasil yang sama juga diperoleh untuk sub sample 1. Namun demikian, koefisien rambatan tidak signifikan untuk sub sampel 2. Dalam sub sampel 2 yakni ketika krisis hutang di Eropa terjadi, hasil estimasi justru menunjukkan adanya transmisi dua arah antara NDF dan perubahan forward rate.

Terkait dengan efek volatilitas rambatan dari pasar dalam negeri ke pasar luar negeri, ditemukan perbedaan yang cukup besar antara hasil estimasi keseluruhan sampel dengan sub sample krisis Subprime dan krisis hutang Eropa. Untuk krisis subprime, transmisi volatilitas dari NDF ke pasar spot dan forward secara statistik signifikan. Namun demikian, untuk keseluruhan sampel, penjalaran volatilitas ini hanya ditemukan dari NDF ke pasar spot.

Efek rambatan volatilitas dari pasar spot dan forward dalam negeri ke pasar NDF luar negeri, secara statistik tidak terbukti untuk keseluruhan sampel. Namun untuk periode krisis subprime dan krisis hutang Eropa, efek rambatan ini secara statistik terbukti signifikan, terutama dari pasar spot ke pasar NDF. Hal ini kemungkinan disebabkan oleh karakteristik pasar Rupiah dalam negeri yang cenderung tipis dengan likuiditas yang terbatas. Volatilitas pasar Rupiah saat kedua krisis ini rata-rata lebih tinggi dibandingkan kondisi normal. Hal ini terkait dengan fenomena flight to quality dan proses deleveraging oleh investor global pada pasar mata uang regional dan pasar negara berkembang. Sementara itu, karena terbatasnya likuiditas pada pasar spot domestik, terjadi pembalikan arah pergerakan modal (capital reversal) yang diakibatkan oleh berlebihnya permintaan atas USD dan memuncaknya volatilitas pada pasar spot. Investor asing seringkali memasuki pasar NDF rupiah untuk memenuhi kebutuhan mereka terhadap USD, yang selanjutnya semakin memperbesar volatilitas pasar.

Tanda positif pada koefisien rambatan, menunjukkan bahwa peningkatan volatilitas pada satu pasar, terkait dengan peningkatan volatilitas pada pasar lain, dan sebaliknya. Paper ini menemukan perbedaan tanda efek rambatan dari pasar NDF ke pasar forward, dimana selama krisis Subprime tandanya negatif, sementara untuk krisis hutang Eropa tandanya positif. Hal ini mengindikasikan bahwa volatilitas efek rambatan dari NDF ke pasar forward berubah dari waktu ke waktu (Morales et.al., 2006).

Paper ini menemukan bahwa efek rambatan rata-rata secara statistik signifikan, sementara volatilitasnya tidak. Lee (2010) menemukan bahwa first moment (return) dan second-moment (volatility) mengandung set informasi yang berbeda, dan memiliki implikasi penting bagi investor dalam hal keputusan investasinya, dan juga penting bagi regulator. 
Efek tidak simetrisnya volatilitas (asymmetric volatility) yang menunjukkan leverage effect, secara statistik terbukti signifikan untuk semua pasar Rupiah, kecuali untuk pasar forward dalam periode krisis Subprime. Jika koefisien volatilitas yang tidak simetris memiliki tanda positif, maka volatilitas nilai tukar Rupiah merespon lebih besar terhadap tekanan depresiasi dibandingkan apresiasi. Demikian pula sebaliknya.

Untuk periode krisis Subprime, paper ini menemukan koefisien yang negatif dan signifikan dalam pasar spot, menunjukkan bahwa volatilitas Rupiah, merespon lebih besar terhadap tekanan apresiasi dibandingkan depresiasi dalam pasar tersebut. Hal ini bertentangan dengan fakta umum dimana pasar Rupiah merespon lebih besar terhadap depresiasi dibandingkan tekanan apresiasi, sejalan dengan hasil penelitian Cairns et.al., (2007) yang menyimpulkan bahwa negara berkembang cenderung mengalami depresiasi mata uang ketika terjadi peningkatan volatilitas. Lebih lanjut, tidak signifikannya koefisien asymmetric volatility untuk pasar forward selama periode krisis Subprime menunjukkan bahwa volatilitas pasar forward merespon baik terhadap apresiasi maupun terhadap depresiasi. 


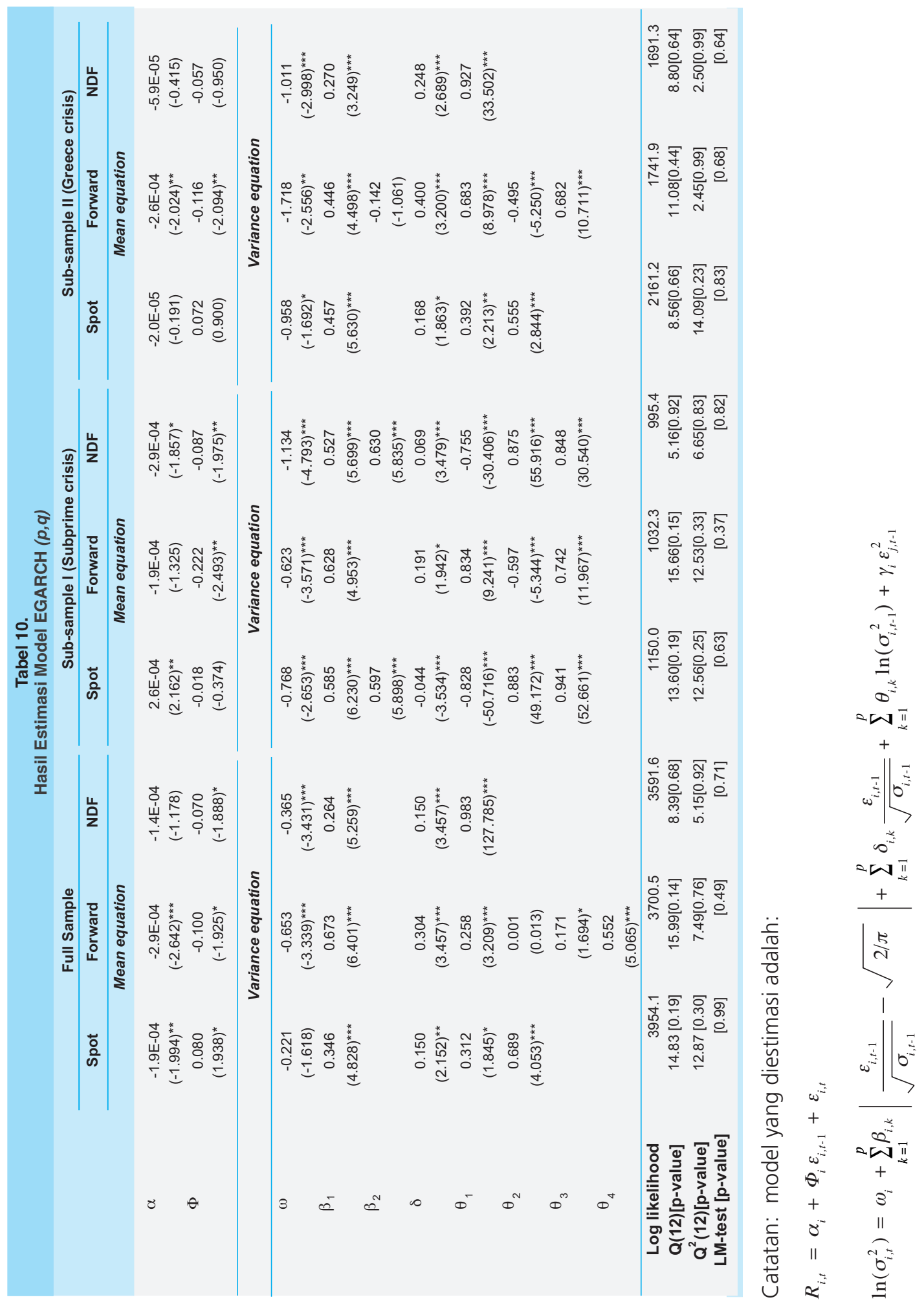




\begin{tabular}{|c|c|c|c|c|}
\hline & \multicolumn{3}{|c|}{$\begin{array}{l}\text { Tabel } 11 . \\
\text { Mean and Volatility Spillover (total sampel) }\end{array}$} & \\
\hline & \multicolumn{4}{|c|}{ Full Sample } \\
\hline & NDF - Spot & Spot - NDF & NDF - Forward & Forward - NDF \\
\hline & \multicolumn{4}{|c|}{ Mean equation } \\
\hline \multirow[t]{2}{*}{$\alpha$} & $-8.2 \mathrm{E}-05$ & $-1.4 \mathrm{E}-04$ & $-1.7 E-04$ & $-1.5 \mathrm{E}-04$ \\
\hline & $(-1.159)$ & $(-1.297)$ & $(-3.347)^{\star \star \star}$ & $(-1.233)$ \\
\hline \multirow[t]{2}{*}{$?$} & 0.281 & 0.122 & 0.489 & -0.008 \\
\hline & $(4.911)^{* * *}$ & -1.354 & $(10.618)^{* * *}$ & $(-0.176)$ \\
\hline \multirow[t]{3}{*}{$\Phi$} & -0.308 & -0.144 & -0.614 & -0.063 \\
\hline & $(-4.168)^{* * *}$ & $(-2.506)^{\star *}$ & $(-10.619)^{* * *}$ & $(-1.293)$ \\
\hline & \multicolumn{4}{|c|}{ Variance equation } \\
\hline \multirow[t]{2}{*}{$\omega$} & -0.364 & -0.398 & -1.362 & -0.369 \\
\hline & $(-3.041)^{\star \star *}$ & $(-3.317)^{\star * *}$ & $(-4.163)^{\star * *}$ & $(-3.388)^{\star \star \star}$ \\
\hline$\beta_{1}$ & 0.147 & 0.333 & 0.897 & 0.271 \\
\hline \multicolumn{5}{|l|}{$\beta_{2}$} \\
\hline \multirow[t]{2}{*}{$\delta$} & 0.090 & 0.155 & 0.255 & 0.151 \\
\hline & $(2.626)^{\star * *}$ & $(3.249)^{\star * *}$ & $(3.238)^{\star \star *}$ & $(3.411)^{* * *}$ \\
\hline \multirow[t]{2}{*}{$\theta_{1}$} & 0.513 & 0.983 & 0.309 & 0.983 \\
\hline & $(2.192)^{\star *}$ & $(109.295)^{\star * *}$ & $(4.266)^{\star \star \star}$ & $(123.919)^{* * *}$ \\
\hline \multirow[t]{2}{*}{$\theta_{2}$} & 0.470 & & 0.170 & \\
\hline & $(2.020)^{\star *}$ & & $(2.652)^{\star \star *}$ & \\
\hline \multirow[t]{2}{*}{$\theta_{3}$} & & & 0.032 & \\
\hline & & & -0.391 & \\
\hline \multirow[t]{2}{*}{$\theta_{4}$} & & & 0.417 & \\
\hline & & & $(5.669)^{\star \star \star}$ & \\
\hline \multirow[t]{2}{*}{$\gamma$} & 0.077 & -0.018 & -0.028 & -0.002 \\
\hline & $(2.378)^{* *}$ & $(-1.467)$ & $(-0.912)$ & $(-0.239)$ \\
\hline
\end{tabular}

Catatan: model yang diestimasi adalah:

$R_{i, t}=\alpha_{i}+\Phi_{i} \varepsilon_{i, t-1}+\partial_{i} R_{j, t-1}+\varepsilon_{i, t}$ $\ln \left(\sigma_{i, t}^{2}\right)=\omega_{i}+\sum_{k=1}^{p} \beta_{i, k}\left|\frac{\varepsilon_{i, t-1}}{\sqrt{\sigma_{i, t-1}}}-\sqrt{2 / \pi}\right|+\sum_{k=1}^{p} \delta_{i, k} \frac{\varepsilon_{i, t-1}}{\sqrt{\sigma_{i, t-1}}}+\sum_{k=1}^{p} \theta_{i, k} \ln \left(\sigma_{i, t-1}^{2}\right)+\gamma_{i} \varepsilon_{j, t-1}^{2}$ 
Tabel 12.

Mean and Volatility Spillover (sub-sampel I)

Sub-sample I (Subprime crisis)

\begin{tabular}{ccc}
\hline NDF - Spot & Spot - NDF & NDF - Forward \\
Mean equation
\end{tabular}

$\begin{array}{ccccc}\alpha & 1.3 \mathrm{E}-04 & -1.1 \mathrm{E}-04 & -1.7 \mathrm{E}-04 & 1.4 \mathrm{E}-04 \\ & (17.198)^{* * *} & (-1.006) & (-3.228)^{* * *} & (0.481) \\ & 0.209 & 0.018 & 0.382 & -0.004 \\ \Phi & (6.341)^{* * *} & (0.146) & (17.095)^{\star * *} & (-0.105) \\ & -0.296 & -0.183 & -0.572 & -0.045 \\ & (-5.691)^{\star * *} & (-2.922)^{\star * *} & (-18.000)^{* * *} & (-0.749)\end{array}$

\begin{tabular}{|c|c|c|c|c|c|}
\hline \multirow[b]{2}{*}{$\omega$} & \multicolumn{5}{|c|}{ Variance equation } \\
\hline & $\begin{array}{c}-1.458 \\
(-4.785)^{\star * *}\end{array}$ & $\begin{array}{c}-1.567 \\
(-5.570)^{\star * *}\end{array}$ & $\begin{array}{c}-2.218 \\
(-7.567)^{\star \star \star}\end{array}$ & & $\begin{array}{c}-0.611 \\
(-2.497)^{* *}\end{array}$ \\
\hline$\beta_{1}$ & $\begin{array}{c}0.649 \\
(6.956)^{\star * *}\end{array}$ & $\begin{array}{c}0.562 \\
(6.534)^{\star * *}\end{array}$ & $\begin{array}{c}1.542 \\
(8.408)^{* * *}\end{array}$ & $=$ & $\begin{array}{c}0.118 \\
(0.866)\end{array}$ \\
\hline$\beta_{2}$ & $\begin{array}{c}0.529 \\
(6.011)^{\star * *}\end{array}$ & $\begin{array}{c}0.606 \\
(6.989)^{\star * *}\end{array}$ & & & $\begin{array}{c}0.323 \\
(2.312)^{* *}\end{array}$ \\
\hline$\delta$ & $\begin{array}{c}-0.151 \\
(-2.733)^{\star \star \star}\end{array}$ & $\begin{array}{c}0.056 \\
(2.006)^{\star *}\end{array}$ & $\begin{array}{l}-0.064 \\
(-0.693)\end{array}$ & & $\begin{array}{c}0.266 \\
(2.346)^{\star *}\end{array}$ \\
\hline$\theta_{1}$ & $\begin{array}{c}-0.240 \\
(-11.307)^{\star * *}\end{array}$ & $\begin{array}{c}-0.736 \\
(-39.769)^{\star \star *}\end{array}$ & $\begin{array}{c}0.022 \\
(0.428)\end{array}$ & & $\begin{array}{c}0.363 \\
(2.585)^{\star * *}\end{array}$ \\
\hline$\theta_{2}$ & $\begin{array}{c}0.294 \\
(15.699)^{* * *}\end{array}$ & $\begin{array}{c}0.795 \\
(57.308)^{* * *}\end{array}$ & $\begin{array}{c}0.477 \\
(13.287)^{* * *}\end{array}$ & & $\begin{array}{c}-0.082 \\
(-0.479)\end{array}$ \\
\hline$\theta_{3}$ & $\begin{array}{c}0.893 \\
(74.465)^{* * *}\end{array}$ & $\begin{array}{c}0.870 \\
(44.985)^{\star * *}\end{array}$ & $\begin{array}{c}0.384 \\
(8.372)^{\star \star *}\end{array}$ & & $\begin{array}{c}0.688 \\
(4.892)^{\star \star *}\end{array}$ \\
\hline$\theta_{4}$ & & & & & \\
\hline$\gamma$ & $\begin{array}{c}0.076 \\
(2.722)^{\star \star \star}\end{array}$ & $\begin{array}{c}0.023 \\
(2.432)^{\star *}\end{array}$ & $\begin{array}{c}-0.079 \\
(-2.165)^{\star *}\end{array}$ & & $\begin{array}{c}-0.002 \\
(-0.092)\end{array}$ \\
\hline
\end{tabular}

Catatan: model yang diestimasi adalah:

$$
\begin{aligned}
& R_{i, t}=\alpha_{i}+\Phi_{i} \varepsilon_{i, t-1}+\partial_{i} R_{j, t-1}+\varepsilon_{i, t} \\
& \ln \left(\sigma_{i, t}^{2}\right)=\omega_{i}+\sum_{k=1}^{p} \beta_{i, k}\left|\frac{\varepsilon_{i, t-1}}{\sqrt{\sigma_{i, t-1}}}-\sqrt{2 / \pi}\right|+\sum_{k=1}^{p} \delta_{i, k} \frac{\varepsilon_{i, t-1}}{\sqrt{\sigma_{i, t-1}}}+\sum_{k=1}^{p} \theta_{i, k} \ln \left(\sigma_{i, t-1}^{2}\right)+\gamma_{i} \varepsilon_{j, t-1}^{2}
\end{aligned}
$$




\begin{tabular}{|c|c|c|c|c|}
\hline \multicolumn{5}{|c|}{$\begin{array}{l}\text { Tabel } 13 . \\
\text { Mean and Volatility Spillover (sub-sampel II) }\end{array}$} \\
\hline & \multicolumn{4}{|c|}{ Sub-sample II (Europe sovereign crisis) } \\
\hline & NDF - Spot & Spot - NDF & NDF - Forward & Forward - NDF \\
\hline & \multicolumn{4}{|c|}{ Mean equation } \\
\hline$\alpha$ & $\begin{array}{l}-1.2 \mathrm{E}-04 \\
(-1.048)\end{array}$ & $\begin{array}{l}-3.2 E-05 \\
(-0.254)\end{array}$ & $\begin{array}{c}-1.2 E-04 \\
(-1.057)\end{array}$ & $\begin{array}{l}-5.1 E-05 \\
(-0.390)\end{array}$ \\
\hline$?$ & $\begin{array}{c}-0.030 \\
(-0.304)\end{array}$ & $\begin{array}{c}0.227 \\
(1.567)\end{array}$ & $\begin{array}{c}0.237 \\
(2.912)^{\star * *}\end{array}$ & $\begin{array}{c}0.109 \\
(2.240)^{* *}\end{array}$ \\
\hline \multirow[t]{2}{*}{$\Phi$} & $\begin{array}{c}0.055 \\
(-0.383)\end{array}$ & $\begin{array}{c}-0.164 \\
(-1.821)^{*}\end{array}$ & $\begin{array}{c}-0.379 \\
(-3.878)^{* * *}\end{array}$ & $\begin{array}{c}-0.129 \\
(-1.879)^{*}\end{array}$ \\
\hline & \multicolumn{4}{|c|}{ Variance equation } \\
\hline$\omega$ & $\begin{array}{c}-0.983 \\
(-2.834)^{* * *}\end{array}$ & $\begin{array}{c}-0.983 \\
(-3.568)^{\star * *}\end{array}$ & $\begin{array}{c}-1.551 \\
(-4.129)^{\star * *}\end{array}$ & $\begin{array}{c}-0.985 \\
(-2.932)^{* * *}\end{array}$ \\
\hline$\beta_{1}$ & $\begin{array}{l}0.155 \\
-1.457\end{array}$ & $\begin{array}{c}0.212 \\
(2.197)^{\star *}\end{array}$ & $\begin{array}{c}0.130 \\
(1.095)\end{array}$ & $\begin{array}{c}0.278 \\
(3.323)^{* * *}\end{array}$ \\
\hline$\beta_{2}$ & & & $\begin{array}{l}-0.168 \\
(-1.466)\end{array}$ & \\
\hline$\delta$ & $\begin{array}{c}0.151 \\
(2.668)^{* * *}\end{array}$ & $\begin{array}{c}0.251 \\
(2.829)^{* * *}\end{array}$ & $\begin{array}{c}0.258 \\
(4.883)^{\star * *}\end{array}$ & $\begin{array}{c}0.250 \\
(2.770)^{\star * *}\end{array}$ \\
\hline$\theta_{1}$ & $\begin{array}{c}0.613 \\
(2.895)^{\star * *}\end{array}$ & $\begin{array}{c}0.929 \\
(41.555)^{\star * *}\end{array}$ & $\begin{array}{c}0.728 \\
(3.167)^{\star * *}\end{array}$ & $\begin{array}{c}0.930 \\
(33.897)^{\star * *}\end{array}$ \\
\hline$\theta_{2}$ & $\begin{array}{c}0.324 \\
(1.545)\end{array}$ & & $\begin{array}{c}0.006 \\
(0.025)\end{array}$ & \\
\hline$\theta_{3}$ & & & $\begin{array}{c}0.137 \\
(1.054)\end{array}$ & \\
\hline$\theta_{4}$ & & & & \\
\hline$\gamma$ & $\begin{array}{c}0.113 \\
(2.626)^{\star * *}\end{array}$ & $\begin{array}{c}0.026 \\
(1.689)^{*}\end{array}$ & $\begin{array}{c}0.098 \\
(2.690)^{\star * *}\end{array}$ & $\begin{array}{c}-0.007 \\
(-0.553)\end{array}$ \\
\hline
\end{tabular}

Catatan: model yang diestimasi adalah:

$$
\begin{aligned}
& R_{i, t}=\alpha_{i}+\Phi_{i} \varepsilon_{i, t-1}+\partial_{i} R_{j, t-1}+\varepsilon_{i, t} \\
& \ln \left(\sigma_{i, t}^{2}\right)=\omega_{i}+\sum_{k=1}^{p} \beta_{i, k}\left|\frac{\varepsilon_{i, t-1}}{\sqrt{\sigma_{i, t-1}}}-\sqrt{2 / \pi}\right|+\sum_{k=1}^{p} \delta_{i, k} \frac{\varepsilon_{i, t-1}}{\sqrt{\sigma_{i, t-1}}}+\sum_{k=1}^{p} \theta_{i, k} \ln \left(\sigma_{i, t-1}^{2}\right)+\gamma_{i} \varepsilon_{j, t-1}^{2}
\end{aligned}
$$

Sama dengan Ma et.al., (2004) dan Misra dan Behera (2006), sangat menarik juga untuk mencermati keterkaitan yield spread antara pasar dalam dan luar negeri. Paper ini menghitung implied yield NDF berdasarkan Persamaan (2). Paper ini juga menggunakan obligasi pemerintah bertenor 10 tahun sebagai proksi pasar domestik. Alasan penggunaannya adalah karena obligasi ini merupakan yang terlikuid di pasar saat ini dan dijadikan sebagai benchmark oleh umumnya investor. Lebih lanjut, yield ini sendiri juga dapat merepresentasikan tekanan terhadap nilai tukar. Ketika yield turun relative terhadap suku bunga pasar luar negeri, maka akan muncul tekanan depresiasi terhadap Rupiah, dan sebaliknya. Juga dapat disebutkan bahwa semakin 


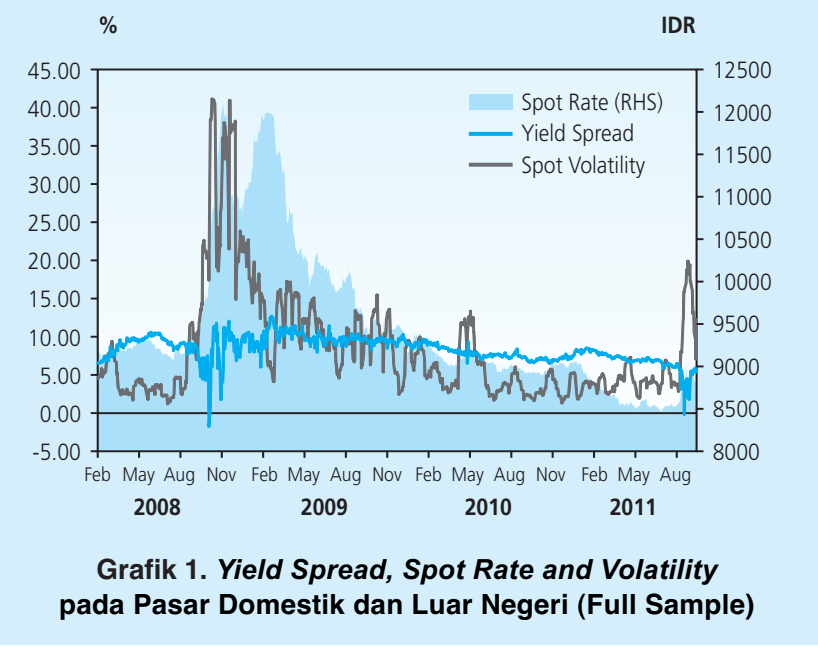

tinggi spread suku bunga domestik terhadap implied yield NDF, maka akan semakin tinggi tekanan apresiasi terhadap Rupiah. Spread yang mengecil antara variabel ini, menunjukkan kecenderungan apresiasi Rupiah karena investor akan mencari alternatif negara lain untuk memperoleh keuntungan yang lebih tinggi. Dengan demikian, variabel nilai dan volatilitas pasar spot dapat diplot untuk melihat kandungan informasinya.

Dari seluruh sampel, paper ini menemukan bahwa spread yang positif antara suku bunga domestik dan rate NDF, akan cenderung diikuti oleh apresiasi Rupiah (Grafik 1). Selain itu, volatilitas cenderung lebih tinggi saat spread tersebut lebih kecil atau bernilai negatif. Meski demikian, paper ini hanya menemukan indikasi yang lemah tentang pengaruh spread terhadap peningkatan tekanan apresiasi.

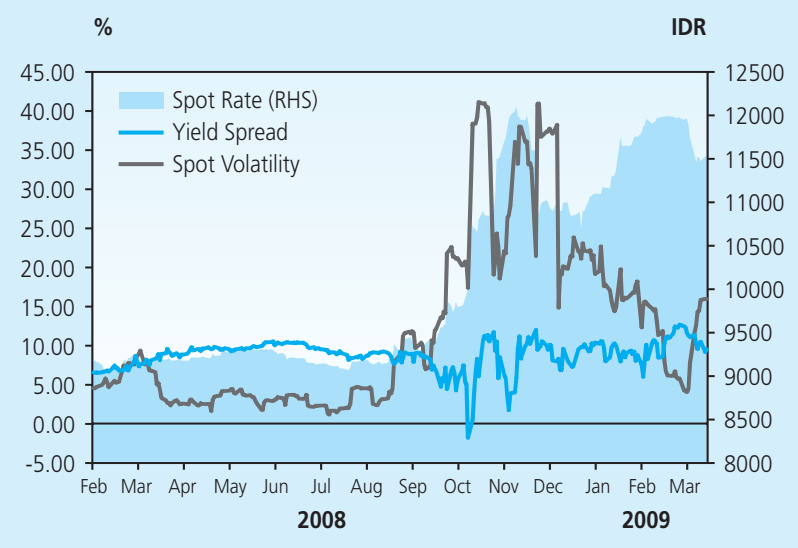

Grafik 2. Yield Spread, Spot Rate and Volatility pada Pasar Domestik dan Luar Negeri (Sub Sample Subprime Crisis) 


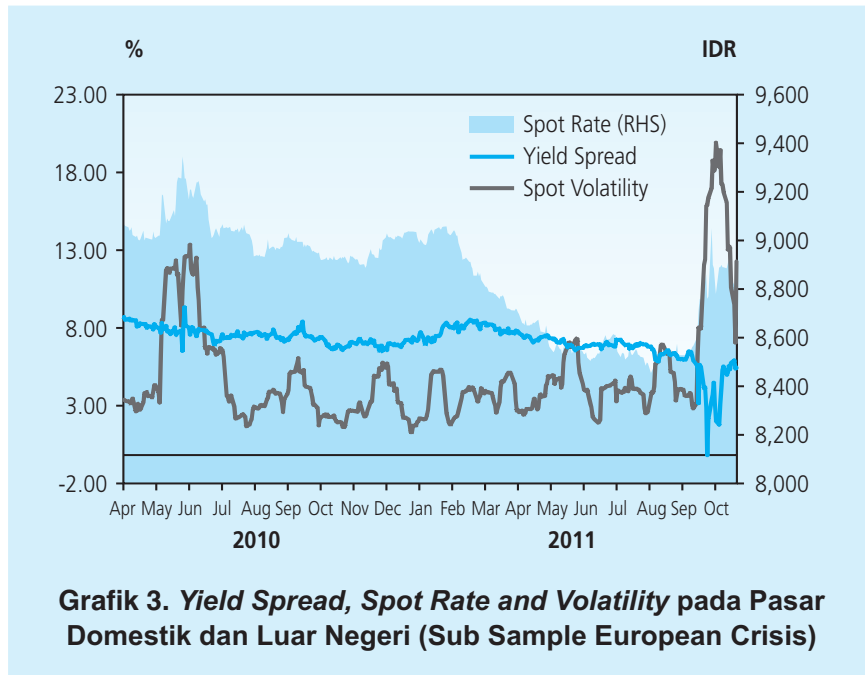

Untuk kedua sub sampel krisis, hasil yang diperoleh sama dengan hasil untuk keseluruhan sampel di atas. Paper ini menemukan bahwa spread yang positif antara suku bunga domestik dengan NDF, cenderung diikuti oleh apresiasi Rupiah, demikian pula sebaliknya (Grafik 2 dan Grafik 3). Paper ini juga mencatat bahwa volatilitas cenderung lebih tinggi saat spread mengecil atau negative, dan hanya terdapat indikasi lemah atas pengaruh spread terhadap tekanan apresiasi Rupiah.

\section{KESIMPULAN}

Paper ini menganalisis perambatan informasi (information spillover) antara pasar Rupiah dalam negeri dengan pasar Rupiah luar negeri. Studi ini menggunakan data harian selang periode 2008 sd. 2011, dan melakukan periodesasi sampel untuk menginvestigasi first-moment dan second-moment dari mekanisme transmisi saat terjadinya krisis global Subprime dan krisis hutang pemerintah Eropa. Dengan menggunakan model EGARCH, paper ini menemukan beberapa kesimpulan empiris.

Pertama adanya persistensi inflasi pada pasar Rupiah. Kedua, leverage effect, terbukti ada dalam nilai tukar Rupiah, yang menunjukkan bahwa pergerakan pasar Rupiah/USD merespon lebih besar terhadap depresiasi dibandingkan dengan tekanan apresiasi. Salah satu konsekuensinya adalah perlunya upaya yang lebih besar bagi pembuat kebijakan untuk menstabilkan nilai tukar Rupiah saat terjadi tekanan depresiasi. Ketiga, dalam nilai rata-rata, efek rambatan bersifat uni-directional atau searah yakni dari NDF ke pasar spot Rupiah, demikian pula ke pasar forward. Secara spesifik saat krisis hutang pemerintah di Eropa terjadi, transmisi antar NDF dan pasar forward bersifat dua arah. Keempat, dalam hal volatilitas, efek rambatan hanya signifikan dari pasar NDF ke pasar spot Rupiah untuk keseluruhan periode. Meski demikian, 
selama periode krisis, terdapat saling ketergantungan volatilitas antara NDF luar negeri dan perubahan nilai tukar spot dalam negeri, sementara transmisi informasi hanya valid dari NDF ke pergerakan pasar forward, dan tidak sebaliknya. Perbedaan perilaku antara efek rambatan rata-rata dalam pasar Rupiah dengan volatilitasnya, penting bagi investor dan bagi regulator. Kelima, spread suku bunga yang negatif dapat memberikan tekanan depresiasi, sementara spread positif menunjukkan tekanan apresiasi.

Kesimpulan diatas membuka peluang studi lebih lanjut terutama dalam hal struktur mikro dari pasar valas, termasuk respon NDF Rupiah terhadap kebijakan moneter dan perilaku pergerakan harian NDF. 


\section{DAFTAR PUSTAKA}

Bekaert, G. dan G. Wu, 2000, "Asymmetric volatility dan risk in equity markets", The Review of Financial Studies, 13(1), pp 1-42.

Cairns, J., C. Ho dan R. N. McCauley, 2007, "Exchange rates dan global volatility: implications for Asia-Pacific currencies", BIS Quarterly Review, March 2007.

Colavecchio, R. dan M. Funke, 2006, "Volatility transmission between Renminbi dan AsiaPacific on-shore dan off-shore US dollar futures", BOFIT Discussion Paper, 16.

Christiansen, C., 2003, "Volatility spillover effects in European bond markets", Working Paper, Aarhus School of Business.

Eagle, R. F. dan V. K. Ng., 1993, "Measuring dan testing the impact of news on volatility", Journal of Finance, 48(5), 1749-1778.

Izawa, H, 2006, "An empirical test of the efficiency hypothesis on the Renminbi NDF in Hongkong market", Discussion Paper Series no. 196, Research Institute for Economic dan Business Administration, Kobe University.

Lipscomb, L., 2005, "An overview of non-deliverable foreign exchange forward markets", Federal Reserve New York Paper.

Lee, C. L., 2010, "An examination of volatility dynamic in Australian REIT futures", The $16^{\text {th }}$ Pacific Rim Real Estate Society Conference, Wellington, New Zealand.

Ma, G., C. Ho dan R. N. McCauley, 2004, "The markets for non-deliverable forwards in Asian currencies", BIS Quarterly Review, June 2004.

Mehra, S. dan H. Behera, 2006, "Non-deliverable foreign exchange forward market: An overview", Reserve Bank of India Occasional Paper, 27(3)

Michayluk, D., P. J. Wilson dan R. Zurbruegg, 2006, "Asymmetric volatility, correlation dan return dynamic between US dan UK real estate markets", Real Estate Economics, 34(1), pp 109-131.

Morales, L. dan M. O’Donnell, 2006, "Volatility spillover between stock prices dan exchange rates: empirical evidence from six APEC economies", All China Economic Conference , Hong Kong , $18^{\text {th }}-20$ th December .

Ng, A., 2000, "Volatility spillover effects from Japan dan US to the Pacific-Basin", Journal of International Money dan Finance, 19, pp 207-233.

Park, J., 2001, "Information flows between non-deliverable forwards (NDF) dan spot markets: Evidence from Korean currency", Pacific Basin Finance Journal, 9(4), pp 363-377, 
Shittu O.I. dan M.J. Asemota, 2009, "Comparison of Criteria for Estimating the Order of Autoregressive Process: A Monte Carlo Approach", European Journal of Scientific Research,vol.30, pp.409-416

Stevenson, S., 2002, "An examination of volatility spillover in REIT returns", Journal of Real Estate Portfolio Management, 8(3), pp 229-238.

Wu, R. S., 2005, "International transmission effect of volatility between the financial markets during the Asian financial crisis", Transition Studies Review, 12(1), pp 19-35. 
Halaman ini sengaja dikosongkan 